\title{
When trade unions succeed: Cases of blocked liberalisation in the common market
}

\author{
MERETHE DOTTERUD LEIREN ${ }^{1} \&$ LOUISA PARKS $^{2}$ \\ ${ }^{1}$ Department of Political Science and Management, University of Agder, Norway and Institute of Transport \\ Economics, Oslo, Norway; ${ }^{2}$ School of Social and Political Sciences, University of Lincoln, UK
}

\begin{abstract}
Despite the generally accepted weakness of trade unions at the European Union level, an analysis of two high profile cases - the Services Directive and the Port Directive - shows that trade unions are able to mobilise effectively at the European level and, within constellations of actors, crucially impact EU decision making. In contrast to common claims that a lack of access to EU institutions makes such groups powerless, it is argued here that the exclusion of large opposing societal groups from consultations is neither a quick nor a sure fire recipe for dismantling opposition. On the contrary, it politicises the process and may lead to opposing groups mobilising in more contentious ways.
\end{abstract}

Keywords: framing; political opportunity structures; liberalisation; services; trade unions

\section{Introduction}

Trade unions have experienced considerable challenges since the introduction of the single market in the European Union (Greenwood 2011). They are much less active in venues related to trade than business interests and nongovernmental organisations (NGOs) and are peripheral in the persuasion networks of EU parliamentarians and bureaucrats (Beyers \& Kerremans 2007: 285). They are also considered weak in the EU literature on the labour movement (Gajewska 2008; Martin \& Ross 2001). However, in recent years interest groups opposing EU proposals have ended up as winning parties after securing the inclusion of their claims in EU legislation, and have even caused the rare phenomenon of the rejection of an EU proposal. Given the existing literature on EU interest groups and transnational mobilisation, such occurrences seem unlikely. It is therefore of interest to discover what combinations of actions and circumstances come together to cause such outcomes.

In order to explore this question, two legislative cases on the completion of the common market have been selected. This is where EU liberalisation policies have been the most sweeping; thus, cases in this area are most likely to be affected by liberalisation. The cases are the campaigns surrounding the Bolkestein Directive, which aimed to liberalise services, and the Port Directive, which aimed at opening the port services market. Both have drawn much attention in the media and in both instances the EU unusually failed to push through market liberalisation measures: the Bolkestein Directive was modified to a large extent and the Port Directive was rejected twice. With their broad-based campaigns, trade unions seem to have played a particularly important role in affecting this outcome. An investigation of these two high-profile cases is therefore useful for exploring to what extent trade unions 
were successful in blocking EU liberalisation as well as the conditions under which they are able to do so. The purpose here is to explain how claims made by unions came to be taken on board in these similar cases rather than to explain which factors led to the different outcomes (rejection versus amendment).

We draw on theoretical approaches from the literature on interest groups and social movements, including framing and opportunity structures. These are relevant as they contribute to understanding what strategies interest groups or social movements adopt when trying to influence policy making, given different opportunities of communication and accessibility, and are complementary rather than mutually exclusive. Despite the generally accepted weakness of trade unions and social NGOs at the EU level, we find that they played an important part in the stories of these two liberalisation attempts, mobilising effectively in the face of closed doors and a lack of opportunities to influence the drafts produced by the Commission. While the trade unions in the case of the Bolkestein Directive were able to create successful coalitions with other societal groups, the trade unions in the case of the Port Directive were able to exploit divisions among the industrial interests in ports, forming a fragmented but successful network with industry interests. Thus, these cases are useful examples of where trade unions, together with other interests, successfully exerted influence over EU policy.

We aim to fill a gap in the literature by first studying effective campaigns by social actors in the EU (see, e.g., Bieler (2011) on the need for such research) and then, by examining two similar cases, we aim to provide a more fine-grained description of the different ways in which trade unions and their allies can remain powerful in influencing EU decision making in the field of market liberalisation. At the same time, this 'paired comparison' contributes to increasing confidence in the findings as the pitfall of exaggerating certain variables is more easily avoided than in single-case analysis (Tarrow 2010). In the next section we review the relevant literature and present our hypotheses. We then briefly present our method and data. After presenting the cases, we conclude that the campaigns of European trade unions, together with other interests, played a decisive role in halting these reform packages. Our conclusions discuss what these findings may imply for EU actors seeking further liberalisation, and for interest groups seeking to impact EU legislation.

\section{Literature review and hypotheses}

Two scholarly approaches to explaining the degrees of influence of interest groups and social movements are framing and political opportunity. While 'framing' refers to how groups define problems and solutions and seek to mobilise support through their utterances, 'political opportunity' structures refer to the qualities of the political context that help or hinder groups seeking to mobilise and influence. These approaches complement each other and are chosen for their respective focus on the political and discursive contexts and actions of campaigning groups. ${ }^{1}$ While the attributes of the different EU institutions affect the kinds of frames most likely to be accepted, frames can affect dynamic political opportunities, for example by bridging issues to recruit new allies. In the following sections, we formulate two hypotheses based on these approaches. 


\section{Framing}

Starting with framing, actors frame issues in order to attach characteristics and definitions, and thus meanings, to people, issues and events. Benford and Snow (2000: 623) provide detail about the different techniques that social movements may employ in framing: frames are used for articulation, amplification, stressing the importance of certain issues, events or beliefs in order to make them more salient. This salience of frames is of particular interest where policy frames are contested, making framing relevant for understanding what happened in the Bolkestein and Port cases, where, as will be shown, frames were contested.

Framing is an ongoing process that must react to outside factors if it is to retain any meaning beyond the groups directly involved in the processes. Frames must interpret new information and respond to other, competing frames in order to ensure superiority. In the social movement framing literature, this idea of salience fits within 'resonance': frames which resonate with the context in which they are embedded will be more believable, and probably appeal to a wider number of people (Gamson \& Modigliani 1989). Resonance is important because while all advocates frame issues, what is interesting is whether others pick these frames up (Baumgartner 2007). Such a statement includes a discursive element of communicating arguments to others.

The distinction between transnational and national production sectors provides an example as to how different frames resonate among trade unions. Bieler (2003) argues that trade unions in export sectors are more favourable toward open borders than unions in domestic production sectors. With increasing liberalisation, national trade unions may become more international as they perceive the possibilities to influence to be wider at the international level (Bieler 2003). This may be of importance for how successful trade unions are in influencing EU policies. Turnbull (2010) suggests that trade unions need to shift from a national focus to a transnational one in order to be influential. Framing plays a role as trade unions first mobilise, drawing on international symbols such as European economic integration to frame national conflicts and then translate such 'threats' into collective action against their employer or the nation-state. Although such international frames are new, they still resonate with the existing understandings of employment (Turnbull 2010).

More generally, a plethora of frame qualities affecting resonance may be found in the literature - for instance, credibility, consistency or centrality and the ability of political leaders to use coherent and clear pictures (Schmidt 2000: 288). For example, visibility and salience are useful factors for prompting interest in society and drawing media attention, thereby increasing the political responsiveness of public opinion. This is relevant for the selected cases of liberalisation as there is not much room for bargaining where conflicts are typically ideological, and public service concerns oppose a market-driven model, focusing on efficiency and customer choice. In the EU, issue definition is particularly important because of the large numbers of access points this organisation provides (Daviter 2007: 655). As mentioned in the next section on political opportunities, different venues require different framing emphases in order to get through and be heard.

Drawing on Noakes and Johnston (2005: 12-16), we use parsimonious categories to assess the resonance of frames that actors use in their campaigns in order to understand under what conditions resonance is important for influencing EU liberalisation outcomes. 
In this view, frame resonance is to do with frame makers (their credibility), frame receivers (their beliefs and values) and the frame itself (cultural compatibility, consistency and relevance).

Based on the framing literature, we hypothesise that if the groups studied in our cases are able to construct salient frames - that is, to communicate and make their issue visible - they are more likely to succeed. Framing is thus viewed as an activity carried out by actors that aims at influencing policy making, and affects their likelihood of success. Political opportunity, explored in the next section, refers to the external contexts of such actors' activities, which are also more or less conducive to actors' interests.

\section{Political opportunity structures}

Another useful body of literature originating in social movement studies but chiming well with conceptualisations in a number of interest group approaches (Princen \& Kerremans 2008; Mahoney \& Baumgartner 2008) discusses political opportunity approaches. These aim to explain social movements or interest groups' actions as rational courses followed in the light of perceived options. Options are judged on the basis of an assessment of key variables in the political context, such as the openness of the system and rules governing protest. In the following we outline our model of political process in the EU with reference to Parks (2009) and the wider literature on political opportunity and influence, given that the only other work focusing on political opportunity in the EU instead addresses questions of mobilisation (Marks \& McAdam 1999). It should be noted that, in line with criticism of 'political opportunity' as a 'catch all' approach in need of specification in terms of 'political opportunity for what' (Meyer \& Minkoff 2004: 1483), we use this approach to investigate the influence of trade unions on EU policy processes, as opposed to the reasons for their mobilisation.

We draw on approaches to political opportunity and influence developed by Parks (2009) and Kolb (2007). Parks argues that it is essential to trace paths of influence, taking into account the diverse properties of each of the EU institutions, as well as various opportunities that may be related to structural features or temporary political situations (such as elections or other upheavals). Kolb highlights the importance of elite allies and enemies, intra-elite conflict, the proximity of elections, public opinion, and the presence and strength of counter-campaigns in terms of dynamic, campaign-specific opportunities. We pay attention to these for each of the institutions of the EU for the particular case in hand.

Marks and McAdam (1999) judge the EU as a whole to be open to dialogue and thus discourage protest on the basis of a sound assessment of the Commission as open to consultation, particularly as a result of its need for information. However, even in cases where the Commission is inclusive, it is likely to prioritise interests that 'sing from the same hymn sheet' (Ruzza 2005), with business groups often seeing an advantage over their less resource-rich counterparts in the NGO sector (Mahoney \& Baumgartner 2008: 1268). While the Commission is indeed open to consultation with civil society, Saurugger (2010) finds that the notion of 'civil society' and robust consultation with participation from unions and NGOs is elusive at the EU level.

The story for the Council and the Parliament is different again. These bodies are more susceptible to influence via protest or other more unconventional actions (Marks \& 
McAdam 1999). Since the Council cannot be lobbied directly, another path towards its influence is indirectly via national governments. The Parliament may also be a protest target by virtue of its status as a directly elected body. This body is also criss-crossed with a number of cleavages that are useful when considering influencing tactics. Crespy (2013: 395-396) lists these cleavages as ideological, geographical and inter-institutional, with the latter emerging as particularly useful for explaining the Parliament's actions in the cases examined here. Given these multiple characteristics of the different institutions of the EU, campaigns incorporating protest have been posited to be more effective than those based on lobbying alone (Bieler 2011:174). Alliances of different types of actors allowing different opportunities to be exploited also appear to be important. By considering each institution individually in our approach we avoid simplistic assessments of our cases as 'one-off' instances where protest has seen a direct effect on policy, exploring instead what appears to lead to trade union influence in the EU, no matter how rare.

From our definition of the EU's political opportunity structure based on the attributes of different institutions, we infer that where a group is excluded from dialogue with the Commission, it will draw on grassroots strategies in an effort to influence the Council and the Parliament - institutions we characterise as more susceptible to traditional ideological arguments and electoral concerns than the Commission. We expect any exclusion of large interest groups in consultations to politicise the legislative process, leading groups to mobilise in more disruptive ways, and thereby making it harder to adopt a policy.

\section{Methods and data}

The method we use for teasing out the mechanisms that led to the policy outcomes in our cases is Tarrow's (2010) 'paired comparison' method. We select two cases that share similarities in outcomes, and expect framing and political opportunity to be important factors in explaining those outcomes. Paired comparison uses causal process analysis to relate elements of the mentioned theories and liberalisation outcomes to one another much as in rich single-case studies, thus retaining the level of detail of such studies. Selecting two cases rather than a single case adds a degree of confidence to the findings, reducing risks of over-emphasising variables that seem critical in a single-case analysis (Tarrow 2010: 244).

Evidence includes policy papers, minutes from hearings in the Parliament and meetings in the Council, consultancy reports, annual reports, calls for action and press releases by interest groups, online newspaper articles from EurActiv, and 18 anonymous, semistructured in-depth interviews. ${ }^{2}$ Seven of these interviews were conducted with actors central to the Bolkestein Directive campaign at the EU level, including representatives of the European Trade Union Confederation (ETUC), Platform of European Social NGOs, European Liaison Committee for Social Housing, European Public Services Union and the Institut Emile Vanderwelde. The remaining 11 relating to the Port Directive were undertaken with relevant maritime interest groups and the EU institutions, including three parliamentarians, two desk officers in the Commission's Directorate-General for Mobility and Transport, three representatives of labour unions, including the Secretary General of the European Sea Ports Organisation, the Secretary General of the European Shipowners' Association and a representative from the relevant German Ministry. 


\section{Cases}

While the first Port Directive was introduced three years prior to the Bolkestein Directive, the second was launched during the same year, 2004. The campaigns on both directives have been hailed as some of the strongest instances of cross-national and European level mobilisation in the history of the EU thus far. Most remarkably, the campaigns ended satisfactorily for the trade unions as significant changes were made to the legislation by the Parliament and accepted by the Council in the case of the Bolkestein Directive, and both Port Directive proposals were rejected by the Parliament. In this section we will briefly describe the two case studies before providing analytical explanations and comparison in the discussion.

\section{The Services Directive: No valentine for Bolkestein}

The Directive on Services in the Internal Market, better known as the 'Bolkestein Directive', presented in January 2004, was a surprise for many of the European actors interested in such legislative goings-on as there had been very little prior consultation (parallel consultations had taken place on services of general interest, but these did not relate to the Bolkestein Directive). From interview evidence, it appears that industry lobbying was concentrated on influencing the Commission at the drafting stage since industry groups were conspicuous by their absence during the remainder of the Directive's passage. The aim of the draft legislation - brainchild of the Commission's Internal Market Directorate General, then headed by Dutch Commissioner Frits Bolkestein - was to achieve an open, common market in services. The central point of contention was the 'Country of Origin Principle', which stated that service providers operating in other countries of the EU would only have to adhere to the laws governing their activities in their homelands, rather than those of the country in which they provided their services. Opposed groups (mostly trade unions) claimed this would result in a 'race to the bottom' and 'social dumping' where service providers from states with lower levels of social protection would successfully force those states with stricter laws to loosen them or face the consequences in terms of lost business. The other major objection was that the Directive risked impinging on national labour law - that is, national collective agreements, workers' rights - and labour codes. Workers from other Member States could be paid different amounts than their colleagues, and national authorities would find it difficult to check their status or treatment.

The first groups to act after the Directive came to light were the trade unions, who bypassed their usual rather ponderous decision-making mechanisms in order to ensure a speedy response. This meant that the European and national levels worked together with greater synergy than usual, according to interviewees, as did organisations from different sectors. For example, the Belgian trade unions organised demonstrations against the Directive as early as June 2004 and via their socialist partners played an important role at the European level. By October, a 'no logo' web petition named 'Stop Bolkestein' appeared, spread through the Belgian Socialist Party's study institute.

In the meantime, the Directive had been passed to the Parliament under the then co-decision procedure. Groups shifted their efforts from activating their own internal networks to targeting the Parliament and the two rapporteurs in particular. Different 
opportunities and methods were adopted: while the ETUC concentrated on the two lead rapporteurs, Uni-Europa concentrated their efforts on those Members of the Parliament (MEPs) outside the Party of European Socialists (PES) who, from previous votes, they felt could be persuaded by union arguments. The responsible committee's hearing on the draft directive, held in November 2004, provided an entry point for social NGOs into the campaign, and was seen by many groups as a turning point. Here, in the words of the interviewees, expert after expert took the floor to condemn the same aspects of the draft directive, repeating the same arguments, and making it clear to one and all that worries were widely shared. Both the trade unions and the social NGOs increased the pressure on the Parliament to ensure the subject remained high on the agenda.

The Parliament was not the only target of the campaigning groups. All those interviewed add that there were, from the beginning, contacts with Presidencies and thus the Council. This is stressed as unusual, and attributed to the fact that the Commission remained so closed to any kind of influence. Demonstrations were also held by the European trade unions, first in November 2004, then again at the spring Social Summit of the European Council in March 2005. Many national demonstrations also took place throughout this period, with some using the 'Stop Bolkestein' slogan launched by the Belgian Socialists. The petition had been translated into many more languages, and e-mail campaigns directed towards the Parliament, the Commission and the heads of state and government of the Member States had also been launched via the website.

The levels of opposition to the draft directive began to pay off in 2005. In February, the new Commission led by Barroso decided to distance itself from the text, with Barroso even going so far as to announce the Commission's intention to amend the text in line with the Parliament's opinion. Following the spring summit, the European Council reiterated the message, allegedly in order to bail out the French President Jacques Chirac in his quest for a 'yes' vote in the referendum on the Constitutional Treaty (Crespy 2010: 1265). French trade unions campaigned against the Constitutional Treaty, using the Bolkestein Directive as evidence of their view of the EU as overly neoliberal and a threat to the French welfare state model. Very quickly the figure of the 'Polish plumber' and fears of large numbers of foreign, cheap workers toppling national systems of social protection came to symbolise the national debate. The Bolkestein issue was thus seen as a way of focusing the debate against a neoliberal Europe in France, and played a not insignificant role in the French 'no' (e.g., Brouard \& Tiberj 2006) - at least in terms of no votes from the left (Della Porta \& Caiani 2007: 2).

Moving towards the end of the campaign, the groups continued to target the Parliament, attempting to secure the best outcome possible in the first reading vote. The two main groups - the PES and the European People's Party (EPP) - were now negotiating a compromise package for the final plenary vote which had been set for February 2006. In order to drive their final message home, the ETUC and others began to plan a demonstration on the day of the vote: 14 February 2006. However, splits between some of the European campaigning groups and those linked to the 'Stop Bolkestein' petition now came to the fore. The hard line text of the petition had, in the view of the ETUC in particular, placed the debate along the lines of opposition to the internal market and European integration per se versus opposition to Bolkestein alone. In the final event, two separate demonstrations took place, although the organisers of 'Stop Bolkestein' and their Belgian 
trade union associates took part in both. Turnout for the trade union march was high at around 50,000 considering the inaccessibility of Strasbourg and the fact that this was a working day. The outcome of the vote, according to the reactions of the various campaigning groups, was favourable. The Country of Origin Principle was deleted, and many exemptions secured, among other changes. Reactions to the Commission's re-drafting of the proposal published on 4 April 2006 were positive as the latter respected the Parliament's central compromise. The Council, led by the Austrian Presidency, also respected the compromise in its common position, and the Directive was adopted in December 2006.

To sum up, the Bolkestein campaign is a story of a combination of sustained advocacy and mass mobilisation by a coalition of groups not often seen in the European context. The fact that the Commission remained closed to dialogue during and after the drafting of the Directive led groups to mobilise quickly in view of what they saw as a great threat. Focusing their campaign at the Parliament and Council, they resorted to protests and marches. European-level groups were also engaged in a thorough and carefully orchestrated lobbying campaign at the Parliament. Together, these factors combined to render the Parliament active and united in its attempt to secure wide-ranging changes to the text of the Directive.

\section{The Port Directive}

On 13 February 2001 the Commission launched the Port Directive, which proposed opening up the port services market and creating common rules for competition between European ports and between the suppliers of port services within single ports. The aim was to introduce the freedom to provide services in the internal market for sea transport and to increase efficiency in inefficient ports, thereby increasing the overall share of maritime transport.

The ship-owners, who were well organised in Brussels and enjoyed frequent contact with the Commission, supported the purpose of the Directive, arguing that competition would increase cost efficiency. Potential suppliers also approved of the idea of increased competition as this would give them access to the market. These interests on the 'demand' side pointed at the unduly high prices of port services. On the contrary, established interests on the 'supply' side - namely port authorities in a number of Member States, terminal operators, pilots, towing and mooring associations and dock workers - voiced their objection to the proposal. Initially, however, they struggled to influence the process. For example, the young European interest group uniting port authorities at the EU level met with some difficulties in speaking with a unified voice due to a distinct organisational divide between the rather effective ports in the northern Member States, which feared intrusion from the EU (which could result, for example, in excessive administrative costs), and the inefficient ports in the southern Member States. Moreover, the trade unions, fearing grave employment and social problems, had few possibilities of being heard. According to interviewees, the trade unions were not influential in the beginning as they were more or less excluded from consultations. The draft proposal and the fact that trade unions were barely consulted in the initial phase infuriated them and resulted in massive protest actions by dock workers. These took place in a number of Member States in 2001, in Spain in 2002 and in several Member States in 2003 (data from Uba \& Uggla 2011). 
The central points of dispute were the liberalisation of pilotage services and allowing ship-owners to handle their own ships (i.e., not employing port workers in the relevant ports, but using their own staff). These issues were particularly controversial due to their quality, environmental, safety and employment aspects. The historical role of trade unions is important in understanding the contention surrounding these points. First, International Labour Organisation (ILO) Dock Work Convention 137 of 1973, which restricts access to dock work for registered workers (i.e., members of a trade union), has historically solved several social problems in this regard. Second, the port workers play an important role in avoiding ship accidents, steering large ships in ports with limited space, ensuring stability and avoiding cargo shifts. These arguments were very compelling as ship accidents can cause huge environmental disasters and are also dangerous for the workers themselves. In addition, actual incidents (the Erika disaster in 1999 and the sinking of Prestige in 2002, which happened during one of the parliamentary hearings in Strasbourg) highlighted the risk of environmental disasters.

Due to such concerns (among other reasons), both the Council and the Parliament emphasised the need for constraints on competition. Throughout the legislative progress of the first Directive they considerably watered-down the proposal and resolved various concerns by including the right of Member States to demand specific criteria when granting authorisations. In the end, the Member States consented to introduce the freedom to provide port services. However, the Parliament was not satisfied and required further exceptions for pilotage services and restrictions on self-handling that the Commission had removed at an earlier point in time. An agreement between the Parliament and the Council was finally reached in conciliation, yet despite the inclusion of exceptions, the joint text was overturned by 20 votes on 20 November 2003 - a rare event in the Parliament's history.

Interviewees suggest that one explanation for this rejection is that the final outcome of conciliation was not well communicated to the political parties. Similarly, trade unions suggest that if they and their concerns had been included in the discursive debates, they would have taken a different stance and sought to influence the process through these debates rather than by initiating protests to the extent they did. Such evidence points to the idea that the lack of input possibilities politicised the process and resulted in the strategy of protest as a means of influence. However, there is no automatic causation between the protests and the rejection of the Port Directive. On the one hand, interviewees argue that the trade unions and their protest actions were important in affecting the outcome as they threatened economic ramifications. On the other hand, a number of interviewees (representatives of Member States and industrial interests) are of the opinion that, for example, the last demonstration in Strasbourg where dock workers threw rocks at the windows of the Parliament, could have resulted in the opposite of what the trade unions wanted as such behaviour is considered unfair or inappropriate.

On 13 October 2004 the Commission put the Port Directive on the agenda for the second time. Yet the Commission did not re-open consultations with the industrial partners or introduce new impact assessments. The lack of input possibilities again politicised the process. The opposition was huge - particularly as the proposal was not identical to the text agreed on in conciliation: disputed issues, including the right of self-handlers to use their own land-based personnel and self-handling for pilotage, had been reintroduced. Again the trade unions organised protest actions, blocking several ports across Europe in 2004, 2005 
and just days before the vote in the Parliament in 2006 (data from Uba \& Uggla 2011). On the day of the vote the unions mobilised 6,000 dock workers from 16 countries to demonstrate in Strasbourg. The large economic impact of such demonstrations directly affected both port authorities and the shipping industry. Industrial interests, largely in favour of liberalising port services, now went against the Port Directive, criticising the Commission for not taking the time to build consensus and provoked by the removal of details from the conciliation agreement that had incorporated a majority of the different demands.

Trade unions together with the other opposing interests possessed resources that could not be ignored by the legislators. ${ }^{3}$ In addition, Member States that were critical towards the Directive informally co-operated with such interests to run against the proposal, despite having given assent in the Council. ${ }^{4}$ Also, as mentioned above, fears of excessive economic liberalism were cited as one of the reasons for the French 'no' to the EU Constitution in May 2005. Under these circumstances it was not the best moment to push for another liberalisation attempt such as the Port Directive. It is also suggested that the new Commissioner, Jacques Barrot from France, was more reluctant to push the Directive forward than his predecessor, Loyola de Palacio. Moreover, throughout the process, the concerns of trade unions and their partners in the Parliament gained considerable media visibility, which added to their recognition. One of the interviewees mentioned that he had never experienced such coverage concerning EU legislation in the media before. On the day of the vote, a boat with a television team followed the demonstration. On 18 January 2006, the Parliament resoundingly rejected the proposal.

In summary, the coalition between interests on the supply side (i.e., port authorities and established port operators) and trade unions created a critical mass to convince the MEPs to vote down the Port Directive. Protests across several Member States increased the public visibility of the conflict. In addition, the Commission aggravated both the trade unions and, in the second round, industrial interests by closing its doors to further input via consultations and impact assessments.

\section{Discussion}

Referring to the hypotheses in the theoretical part, the two cases highlight interesting findings as to why the neoliberal discourse failed. Regarding political opportunities, in both cases the trade unions met with closed doors in the Commission. In the Bolkestein case, the actors were taken by surprise by the sudden introduction of the Services Directive, which had not been discussed with them during the drafting stage. Similarly, trade unions in the port case did not have the opportunity to influence the policy through consultations. In both cases, trade unions therefore sought to influence the Parliament and Council both through advocacy and by mobilising protests in the streets and blocking ports. These mobilisations contributed to successful outcomes, but - as in the Bolkestein case - demonstrations alone were not a sufficient condition for influencing the parliamentarians to vote down the Directive. The evidence from interviews with both Member State representatives and those in the industry suggests that the protests could have had the opposite effect: retaliation from decision makers in the Council and the Parliament (since protesters threw rocks at EU buildings). However, the port workers were successful as they were able to exploit 
divisions among industry interests to their advantage. The protests seen in the Bolkestein case were less confrontational in nature, and worked well in terms of physically demonstrating the sheer numbers involved in the opposition to the Directive, thus supporting the extensive advocacy work carried out at the Parliament, as well as the (apparent) unity of the coalition between social NGOs, trade unions and social movements. Protests thus contributed heavily to, but were not solely the cause of, the heavy amendment of the Services Directive.

The coalitions of groups campaigning against these two directives emerge as important in the navigation of political opportunities and threats. Although the trade unions in the port sector seem exceptionally strong due to their ability to control important transport nodes where blocking has considerable economic ramifications for the industry, they were only able to claim their victory because industry interests on the supply side were divided on the issue and sided with the trade unions against the Port Directive. Similarly, in the Bolkestein case, trade unions were influential because they found allies in other interest groups as well as social movements. Thus, the paired comparison contributes by suggesting we avoid placing too much emphasis on the leverage of trade unions as an isolated group, highlighting instead the importance of actor constellations. We therefore argue that it is the ability to form coalitions that appears as important in these cases, independently of the different scopes and production areas involved.

In sum, our hypothesis about the exclusion of large interest groups finds confirmation a closed Commission and a lack of dialogue did indeed lead to the use of more disruptive strategies and politicise the issues in these cases, resulting in the Parliament acting according to the inter-institutional cleavage as we will see below. The frames that the trade unions and their allies adopted were beneficial for their purpose, aiming to avoid liberalisation reform. In both cases they were able to use visible arguments that highlighted the possible negative consequences of the suggested reforms. In the Bolkestein case, initially scattered frames converged around social dumping and the 'race to the bottom' arguments, along with concerns about workers' rights and collective agreements. A split in framing was observed between the unions and the more hard-line 'Stop Bolkestein' petition, but importantly the different frames did not conflict with one another. The resonance of these frames was aided by this coherence, their importance to the target audience (in that collective agreements and social protection are of central importance to unionised workers) and an array of actors from European trade unions to social movement organisations proposing them. In the port case, safety and environmental disasters created strong arguments in the fight against liberalisation of port services. These were credible as recent ship accidents highlighted the inherent danger of vessels at sea, and the importance of port workers in avoiding such disasters. The frame resonated with the context in which it was embedded, making the safety and environmental arguments believable. In addition, concerns of social problems due to job losses where ports are important employers and tax providers did not contest the frames of safety and environmental concerns - rather these frames increased the strength of each.

Moreover, recent statistical research on protests in the EU (Uba \& Uggla 2011) suggests that outbreaks of protest related to EU policies correlate with certain debates and events. Both cases resonated with the context of the French 'no' to the EU Constitution, allowing frames to be communicated and made visible via media coverage. The Bolkestein Directive 
in particular was picked out as representative of 'neoliberal' Europe in the French debate, which contributed to heightened interest in the issue. Both campaigns also coincide with a noted resurgence of social, traditionally left-wing questions in Europe (e.g., Mathers 2007) and growing unrest running parallel to deeper integration. Indeed, a glance at the Eurobarometer surveys for the years 2001 to 2006 reveals that social questions and the fight against unemployment have consistently topped the list of the issues judged most important in Europe. Each directive was thus perceived as yet another unpopular liberalisation attempt, and the European dimension focused on as the appropriate level in line with Turnbull's (2010) arguments. Again we find some confirmation of our hypothesis concerning the contribution of salient frames in gauging the influence of EU campaigns - salient frames resonated with broader themes in society and attention to EU issues led to higher visibility and effects on public opinion. Linking this to the political opportunity approach, interest from public opinion can be said to have contributed to influencing EU institutions to change or reject the cases in hand.

These campaigns also share another apparently important similarity leading to the successful efforts of trade union campaigns: the activation of the Parliament as an ally. The Parliament is crossed by a number of cleavages and cannot be assumed to be a unitary actor. However, in the Bolkestein case this body acted in the perspective of the inter-institutional cleavage to stake its claim to power within the EU inter-institutional triangle. In the port case, the Parliament was divided when the first draft directive was rejected (it was almost accepted). However, when the Directive was reintroduced, there was no doubt as to the Parliament's position against the proposal, offended by what they saw as the Commission's lack of respect for their democratic decision, and supported by both unions and industrial interests. In the Bolkestein campaign, the Parliament also rose to the challenge following strong lobbying, demonstrations and the declaration from Barroso, working hard and across ideological divides to arrive at a text that was acceptable to the trade unions. The importance of gaining the Parliament as an ally in campaigns involving legislation under the 'ordinary legislative procedure' thus seems clear. The port case reinforces this point: some of the Member States continued to run against the Port Directive in conversations with parliamentarians despite having already assented to the proposal in the Council. This fact shows that there is a discrepancy between how national governments view their roles in the Council (in which there is a strong norm of consensus) and how they see their role nationally or even in relation to the Parliament.

\section{Conclusions}

In this paired comparison of two unusual cases of failed EU liberalisation, we have examined how framing and political opportunities in the EU can help us to understand the paths leading to outcomes where apparently weak actors claim victory in EU policy making. We hypothesised that resonant frames would aid in such successes, and that exclusion from dialogue with the Commission would politicise campaigns, making policies harder to pass. Our two cases provide some support for these hypotheses, and also highlight the importance of coalitions and allies. ${ }^{5}$ The discussion of the cases also shows how these two 
approaches complement one another, with a framing approach drawing in important discursive elements often overlooked in strict political opportunity analyses. While a comparison of only two rather unusual cases does not provide grounds for any generalisation, we think these peculiar cases throw up some important findings for the study of the EU policy process and how it is influenced.

More specifically, the analysis highlights two key conclusions. First, to exclude large, opposing societal groups from consultations does not result in a quick solution for achieving further liberalisation. On the contrary, it may aggravate them, thereby making it more difficult for reformers to achieve policy change than when such opposing interests are included in consultations. For the Commission and other proponents of liberalisation who aim for further market liberalisation this is a useful lesson. Second, although certain trade unions control important resources that make them powerful in decision-making processes, our conclusion is that this condition does not have to be present for trade unions to be influential. Building coalitions (including elite allies such as the Parliament), resonant frames and acting strategically with regard to political opportunities are important for campaigns by groups seeking to influence EU policy. Third, the analysis shows that it is possible for large societal groups to limit or reject market liberalisation in the EU. Key to such a result is the ability of societal groups to effectively mobilise against a proposal and exploit divisions among industry interests. Evidence from other liberalisation cases partly supports such findings (e.g., Höpner \& Schäfer 2010). For instance, due to limited resources and extensive agendas as compared to other interests, trade unions were not particularly active at the EU level in the case of the Postal Directive, which 'fully' opened the market to competition, or the Public Service Obligations for Public Passenger Transport Regulation, which introduced competitive tendering as a key principle of service delivery (Leiren 2013).

Given the claim in the literature that trade unions struggle with collective action problems, future research should focus on how and when interest groups at the EU level are able to overcome collective action issues and act more quickly. The aid given to both cases by the debates over the EU Constitutional Treaty also hints that at times when the EU is particularly visible - and unpopular - in public opinion, blocking liberalisation may be easier due to some level of EU concern with its image and (lack of) perceived legitimacy. An interesting question is whether 'backing down' may on occasion be viewed as advantageous to the EU's reputation as a whole.

This is particularly relevant as the EU affects increasingly salient issues, which in turn increases politicisation and challenges the content of EU policies and decision-making processes. It is also interesting in an era of increasing scepticism over the EU - for example, as a consequence of the current crises, including demonstrations in Greece, discussions in the United Kingdom to exit the Union, and the Italian protest vote against premier Monti, seen by many Italians as 'imposed' by the EU. However, it remains to be seen whether such opposition will last or whether the current crises will contribute to yet more liberalisation. In May 2013 the Commission published its new communication on ports - including its third attempt at liberalising the market for access to port services in the EU. Controversial aspects of the Services Directive, many unions argue, have since been brought in by other means. Whether these short-term successes of trade unions translate into longer term influence over the EU agenda is a subject for further study. 


\section{Acknowledgements}

We are grateful to three anonymous referees for comments on earlier drafts of this article as well as to the participants of the Workshop 'Beyond Class Politics: How Parties, Voters, Media and Unions Shape Public Policy' at the ECPR Joint Sessions Conference in Mainz, 11-16 March 2013. We would also like to thank the interviewees for their insights that have been important for writing this article.

\section{Notes}

1. In the literature on social movements this mutual relationship between framing and political opportunity is often captured through the discursive opportunity approach, which focuses on cultural contextual elements. Our attention to framing processes serves to overcome criticisms of the emphasis on the political of the political opportunity approach (see, in particular, Koopmans \& Statham 1999), and we do not therefore add a discursive approach here.

2. The research projects these interviews were originally carried out for had different scopes, which accounts for this discrepancy in the interview samples for the two cases. Only when our separate pieces of work were complete did we note the striking similarities between them and decide to carry out this paired comparison. The interviews were carried out between March 2005 and March 2006 (the Bolkestein Directive) and March-June 2011 (the Port Directive).

3. Interview with an industry interest group.

4. Interview with a Member State representative.

5. Testing the hypothesis on framing in a more robust manner would require extensive analysis of a variety of documents. How the media portrayed the frames expressed in trade union documents, and how these were perceived by the public, would for example provide a more complete picture. A formal frame analysis of documents produced by campaigning groups at different territorial levels and at differed crucial junctures was carried out for the Services Directive, and shows the internal consistency, credibility (in that arguments are based on sound analyses of the proposed legislation and are shared across groups) and salience (insofar as touching on issues of core importance to unionised workers, such as the right to strike and collective bargaining). Frame grids are available on request from the authors. Evidence from interviews and extensive reading of documents in the Port Directive case show similar indications.

\section{References}

Baumgartner, F.R. (2007). EU lobbying: A view from the US. Journal of European Public Policy 14(3): 482-488.

Benford, R.D. \& Snow, D.A. (2000). Framing processes and social movements: An overview and assessment. Annual Review of Sociology 26: 611-639.

Beyers, J. \& Kerremans, B. (2007). The press coverage of trade issues: A comparative analysis of public agenda-setting and trade politics. Journal of European Public Policy 14(2): 269-292.

Bieler, A. (2003). Labour, neo-liberalism and the conflict over economic and monetary union: A comparative analysis of British and German trade unions. German Politics 12(2): 24-44.

Bieler, A. (2011). Labour, new social movements and the resistance to neoliberal restructuring in Europe. New Political Economy 16(2): 163-183.

Brouard, S. \& Tiberj, V. (2006). The French referendum: The not so simple act of saying nay. Political Science and Politics 39(2): 261-268.

Crespy, A. (2010). When 'Bolkestein' is trapped by the French anti-liberal discourse: A discursiveinstitutionalist account of preference formation in the realm of European Union multi-level politics. Journal of European Public Policy 17(8): 1253-1270.

Crespy, A. (2013). Comment le rideau est tombé sur ACTA: Mobilisations 2.0 et parlementarisme dans l’Union européenne. Annuaire Français des Relations Internationales 14: 392-404. 
Daviter, F. (2007). Policy framing in the European Union. Journal of European Public Policy 14(4): 654-666.

Della Porta, D. \& Caiani, M. (2007). Europeanization from below? Social movements and Europe. Mobilization 12(1): 1-20.

Gajewska, K. (2008). The emergence of a European labour protest movement? European Journal of Industrial Relations 14(1): 104-221.

Gamson, W.A. \& Modigliani, A. (1989). Media discourse and public opinion on nuclear power: A constructionist approach. American Journal of Sociology 95(1): 1-37.

Greenwood, J. (2011). Interest representation in the European Union. Houndmills: Palgrave Macmillan.

Höpner, M. \& Schäfer, A. (2010). A new phase of European integration: Organized capitalisms in postRicardian Europe. West European Politics 33(2): 344-368.

Kolb, F. (2007). Protest and opportunities: The political outcomes of social movements. Frankfurt: Campus Verlag.

Koopmans, R. \& Statham, P. (1999). Ethnic and civic conceptions of nationhood and the differential success of the extreme right in Germany and Italy. In M. Giugni, D. McAdam and C. Tilly (eds), How social movements matter. Minneapolis, MN: University of Minnesota Press.

Leiren, M.D. (2013). Differentiated European Integration: Liberalisation of Post, Public Transport and Ports. Doctoral dissertation, Faculty of Economics and Social Sciences, University of Agder.

Mahoney, C. \& Baumgartner, F. (2008). Converging perspectives on interest group research in Europe and America. West European Politics 31(6): 1253-1273.

Marks, G. \& McAdam, D. (1999). On the relationship of political opportunities to the form of collective action: The case of the European Union. In D. della Porta, H. Kriesi \& D. Rucht (eds), Social movements in a globalizing world. Basingstoke: Palgrave Macmillan.

Martin, A. \& Ross, G. (2001). Trade union organizing at the European level: The dilemma of borrowed resources. In D. Imig \& S. Tarrow (eds), Contentious Europeans: Protest and politics in an emerging polity. Lanham, MD: Rowman \& Littlefield.

Mathers, A. (2007). Struggling for a social Europe: Neoliberal globalization and the birth of a European social movement. Aldershot: Ashgate.

Meyer, D. \& Minkoff, D. (2004). Conceptualizing political opportunity. Social Forces 82(4): 1457-1492.

Noakes, J.A. \& Johnston, H. (2005). Frames of protest: A road map to a perspective. In Frames of protest: Social movements and the framing perspective. Lanham, MD: Rowman \& Littlefield.

Parks, L. (2009). National and European? Protesting the Lisbon agenda and the services directive in the European Union. In L. Bruszt \& R. Holzhacker (eds), The transnationalization of economies, states and civil societies. New York: Springer.

Princen, S. \& Kerremans, B. (2008). Opportunity structures in the EU multi-level system. West European Politics 31(6): 1129-1146.

Ruzza, C. (2005). Europe and civil society: Movement coalitions and European governance. Manchester: Manchester University Press.

Saurugger, S. (2010). The social construction of the participatory turn: The emergence of a norm in the European Union. European Journal of Political Research 49(4): 471-495.

Schmidt, V.A. (2000). Democracy and discourse in an integrating Europe and a globalising world. European Law Journal 6(3): 277-300.

Tarrow, S. (2010). The strategy of paired comparison: Toward a theory of practice. Comparative Political Studies 43(2): 230-259.

Turnbull, P. (2010). From social conflict to social dialogue: Counter-mobilization on the European waterfront. European Journal of Industrial Relations 16(4): 333-349.

Uba, K. \& Uggla, F. (2011). Protest actions against the European Union, 1992-2007. West European Politics 34(2): 384-393.

Address for correspondence: Merethe Dotterud Leiren, Institute of Transport Economics, Gaustadálleen 21, 0349 Oslo, Norway. E-mail: mdl@toi.no 